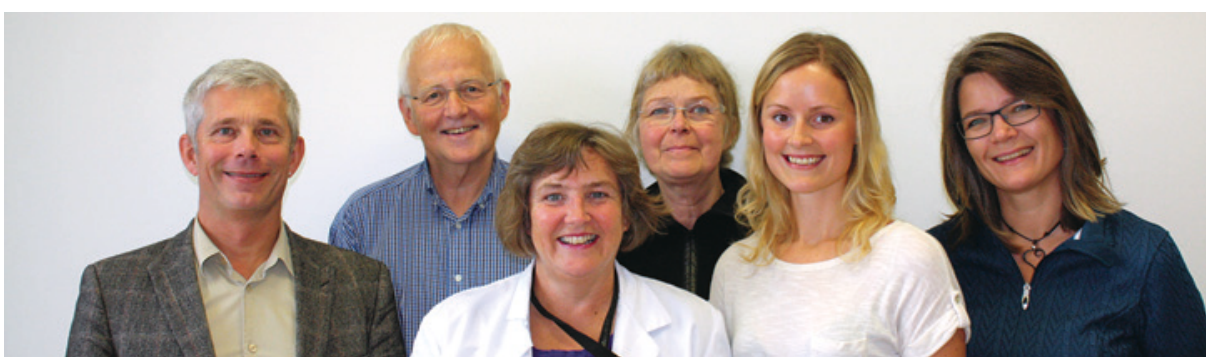

Fra venstre Stian Lydersen, Torstein Vik, Runa Heimstad, Rigmor Austgulen, Kristin Melheim Strand og AnnCharlotte Iversen. Medforfattere Guro Andersen og Lorentz Irgens var ikke til stede da bildet ble tatt. Foto privat

\title{
Er preeklampsi en risikofaktor for cerebral parese?
}

Preeklampsi er en vanlig svangerskapskomplikasjon. Det kan føre til veksthemming hos fosteret og prematur fødsel. I en norsk studie har man undersøkt om preeklampsi gir økt risiko for cerebral parese hos barnet.

Cerebral parese er den vanligste årsaken til motorisk funksjonshemning hos barn. Prematur fødsel og det å være født med lav fødselsvekt i forhold til svangerskapets lengde (SGA) er viktige risikofaktorer. I noen studier er det funnet økt risiko for cerebral parese etter preeklampsi hos barn født til termin (1), mens det $\mathrm{i}$ andre ikke er funnet noen slik sammenheng (2). Det finnes ingen tidligere studier der man har undersøkt hvorvidt økt risiko for cerebral parese etter preeklampsi kan skyldes intrauterin veksthemming. Ettersom det siste er vanskelig å diagnostisere, brukes fortsatt lav fødselsvekt $\mathrm{i}$ forhold til svangerskapets lengde som indikator på at barnet er veksthemmet.

I en ny norsk studie ble data fra Cerebral parese-registeret i Norge koblet med data fra Medisinsk fødselsregister for barn født i perioden 1996-2006 for å undersøke om preeklampsi er en risikofaktor for cerebral parese (3). Studien omfattet 849 barn med cerebral parese og over 600000 barn uten. Preeklampsi var assosiert med økt risiko for cerebral parese (oddsratio 2,5; $95 \% \mathrm{KI}$ $2,0-3,2)$. Den økte risikoen var assosiert med for tidlig fødsel og lav fødselsvekt i forhold til svangerskapets lengde. Også barn født til termin som hadde lav fødselsvekt i forhold til svangerskapets lengde hadde økt risiko for cerebral parese. Preeklampsi var derimot ikke assosiert med økt risiko for cerebral parese hos barn født til termin med normal fødselsvekt. Dette tyder på at det ikke er noen direkte effekt av preeklampsi på risiko for cerebral parese.

- Preeklampsi medfører ikke økt risiko for cerebral parese så lenge barnet fødes til termin med normal fødselsvekt, sier Kristin Melheim Strand, som er førsteforfatter av artikkelen og medisinstudent ved Norges teknisk-naturvitenskapelige universitet. - I preeklamptiske svangerskap blir kvinnen oftest forløst på grunn av dette eller på grunn av alvorlig intrauterin veksthemming hos barnet. Våre resultater kan tyde på at tidlige symptomer på slik veksthemming bør vektlegges i større grad når forløsning ved preeklampsi vurderes. Det må understrekes at studien er observasjonell og at funnene må bekreftes og utprøves før en generell anbefaling kan gis.

\section{Forskningsgruppe for cerebral parese} Studien ble gjennomført i forskningsgruppen for cerebral parese ved Institutt for laboratoriemedisin, barne- og kvinnesykdommer, Norges teknisk-naturvitenskapelige universitet, i samarbeid med Cerebral parese-registeret i Norge ved Sykehuset i Vestfold og Medisinsk fødselsregister. Forskningsgruppen har publisert en rekke studier om risikofaktorer, komorbiditet, behandling og habilitering av barn med cerebral parese. Den ledes av professor Torstein Vik. Gruppen er en del av et stort internasjonalt nettverk med forskere i Europa og USA.

Førsteforfatter av artikkelen er medisinstudent Kristin Melheim Strand og sisteforfatter er Torstein Vik, som leder forskninsgruppen. Medforfattere er Guro L. Andersen, Lorentz Irgens, Runa Heimstad, Rigmor Austgulen, Ann-Charlotte Iversen og Stian Lydersen.

\section{Matilde Risopatron Berg}

matilde.risopatron.berg@legeforeningen.no

Tidsskriftet

\section{Litteratur}

1. Thorngren-Jerneck K, Herbst A. Perinatal factors associated with cerebral palsy in children born in Sweden. Obstet Gynecol 2006; 108: 1499-505.

2. Wu CS, Nohr EA, Bech BH et al. Health of children born to mothers who had preeclampsia: a population-based cohort study. Am J Obstet Gynecol 2009; 201: e1, e10

3. Strand KM, Heimstad R, Iversen AC et al. Mediators of the association between pre-eclampsia and cerebral palsy: population based cohort study. BMJ 2013; 347: f4089.
Ordforklaringer

Cerebral parese: Bevegelsesforstyrrelser som skyldes en utviklingsfeil eller skade i den umodne hjernen, oppstått i fosterlivet, i tiden rundt $f ø d s e l e n$ eller de første levemånedene.

Lav fødselsvekt i forhold til svangerskapets lengde: På engelsk «small for gestational age» (SGA), definert som fødselsvekt under 10-prosentilen korrigert for svangerskapsalder og kjønn.

Preeklampsi: Svangerskapskomplikasjon kjennetegnet av hypertensjon og proteinuri som oppstår etter 20. svangerskapsuke.

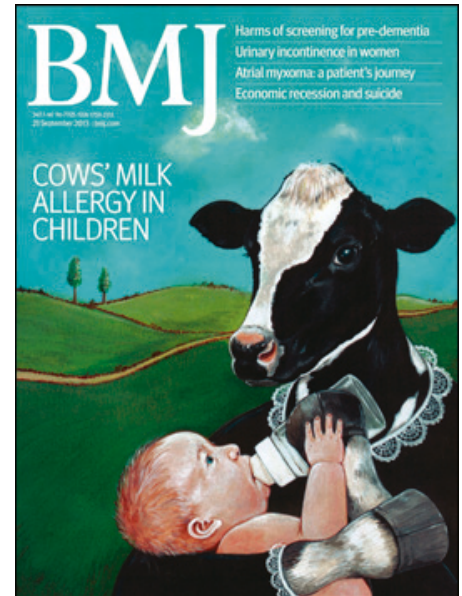

Artikkelen ble publisert i $B M J$ (www.bmj.com), en av de fem store medisinske tidsskriftene. 